\title{
THE ACT OF PLAYING WITHIN THE HOSPITAL CONTEXT IN THE VISION OF THE ACCOMPANYING PERSONS OF THE HOSPITALISED CHILDREN
}

\author{
Lyana Carvalho e Sousa ${ }^{1}$, Alberto De Vitta ${ }^{1}$, José Milton de Lima ${ }^{2}$, \\ Fabiana Cristina Frigieri De Vitta ${ }^{2}$
}

DOI: http://dx.doi.org/10.7322/jhgd.96766

\begin{abstract}
Introduction: the infant hospitalisation may put at risk the normal development of the children due to the breaking of their routine and the adjustment to the new reality process. There are several initiatives to promote spaces in hospitals so that the children can have contact with recreational activities. There are many variables that may influence the children's attitude towards the possibility of playful activities, among them the involvement of the accompanying persons. It is essential to learn their interpretation of the playing activities in the hospital context and which characteristics are associated with this activity in order to reach better planning of the assistance. Objective: this study aimed to examine the opinion of the accompanying persons on promoting play during the children's hospitalisation. Methods: therefore, the accompanying persons answered questionnaires during that period of hospitalisation. Data were analysed using descriptive statistics and content analysis. Results: 65 mothers of hospitalised children, mostly accompanied patients aged from 26 years old. All of them confirmed that the children should attend the playroom since it helps in recovery, providing relief from suffering, calming them and thus relieving tensions. Conclusion: as a conclusion, the accompanying persons highlight the importance of the playroom in the context of hospitalisation of children to soothe its effects of and help in the development of the children.
\end{abstract}

Key words: play, hospital, accompanying persons.

\section{INTRODUCTION}

Many topics have been studied on the environmental context and its relationship to human development, including hospital environments and their relation to the children's development. ${ }^{1-6}$

Hospitalisation may compromise the normal development of the children, both for breaking their routine and the process of adjusting to the new reality (hospital routine: examinations, painful procedures, schedules, visits, etc.) so it may result in the impairment of the physical, emotional and intellectual development. In case of hospitalisation, children leave ordinary things behind, however, regarded as essential to their development: parents, home, siblings, school, friends, pets and toys. ${ }^{1,7-9}$

Carvalho and Begnis ${ }^{8}$ and Pedrosa et al. ${ }^{7}$ emphasize the need to create environments that can favour children to continue a variety of activities so that the factors resulting from hospitalisation do not interfere with their development and emphasize that "all institutions devoted to child care spaces should be recognized as integral development"8 (p. 110).
Several authors ${ }^{1,10}$ highlight that the playing process produces a distinctive, singular reality as it modifies the routine of the hospital stay, allowing the children to elaborate such experience, as well as it promotes the continuation of their development. Another study ${ }^{8}$ based on the importance of the infant playing activity found that such act is a positive strategy for coping with the stress caused by invasive procedures derived from hospitalisation.

In a study on the playing activity within the hospital as a tool through which children regulate their feelings of anger and sadness, the authors state that the playing activity gives the children the chance to experience a "new content which appears in that situation and the construction of important significance in the conception of themselves and of their emotions that are part of their experiences in and out of hospital."

Such play areas which are organised in the institution by a professional team are designed as special waiting rooms, leading the procedures, consultations and examinations less distressing as

\footnotetext{
1 Universidade Sagrado Coração, Rua Ir. Arminda, 10-50, Jd. Brasil, CEP 17011-160 - Bauru, SP, Brasil.

2 Universidade Estadual Paulista, Rua Roberto Simonsen, 305, CEP 19060-900 - P. Prudente, SP, Brasil. Corresponding author: fabianavitta@gmail.com
} 
well as they contribute to a doable incorporated experience by the children (p. 646) ${ }^{2}$.

The authors ${ }^{2}$ also emphasize that considering health promotion in a biopsychosocial context, the playful resources can help in the diagnostic and interventional fields since they are applied with the assistance of trained and competent professionals.

Several initiatives can be detected to promote spaces in hospitals that make possible to the children to have contact with recreational activities, especially after the hospital humanization movement initiated by the Ministry of Health since $2000^{11}$.

Act number 11.104 of March 21, 2005 reinforces the importance of the playing activity on health by requiring the installation of playrooms in health units that assist infant patients ${ }^{12}$. Another purpose of the playroom is to provide a less traumatic and more cheerful hospital environment, enabling better conditions of staying, recovering, as well as it prepares the children to face new experienced situations preserving their emotional health and thus continuing the process of their development and the preparation for returning home ${ }^{3}$.

In Brazil, even not playing a significant role, hospital playrooms can become a proper procedure to be constructed and operated within the hospital space. The structuring of the playroom should take into account the organisation of the space and materials based on the infant universe. Toys, painting and drawing, logic blocks, assembly parts, music, drama, modeling, among others, may favour the development of creativity, expression of feelings and stimulation of neuropsychomotor skills ${ }^{13}$.

The accompanying persons, usually the children's parents, are involved in all the problems of hospitalisation.

The problem extends to the family, mostly to the accompanying person, generally the mother of the hospitalised child. She is the recipient of all sorrow, suffering, tears, groans of her young child, moved by his state of health and the conditions of a context that is adverse to him. She also resents this environment, often without proper accommodation she may need, and especially without the proper definition of her own role regarding her sick child (p. 111) ${ }^{5}$.

A study ${ }^{10}$ that examined the significance of promoting the playing activity in a healthcare environment for health professionals working with this proposal found important data. Some of these results were compared with the effect that the playing activity had on the accompanying persons and on the relationship with the children, as the association between playing and normality; the facilitation of the interaction between the health professionals, the children and their companions and as a remaker of bonds that can may be fragmented within the family group (which may be disorganised by the disease).

The presence of an adult in recreational activities in the hospital context is important since it represents the partner during the game, contributing to the expression of the children, conflict management and as a support in situations where they need warm care when coping with painful and invasive procedures ${ }^{12}$. Moreover, the playing activity has an important influence on the prevention and promotion of health in parents of normal children, "the goal is to ensure a harmonious development of the children, improve relationships between parents and children and help the whole family to have a better quality of life"14.

Thus, the role of the accompanying persons and their understanding of the activities available to children within the context of the hospital stay cannot be neglected. To learn their interpretation of the playing activity within the hospital context and which qualities (positive and/or negative) that are associated with this activity with regard to the welfare of the children is of extreme importance for better planning of the necessary care.

From this perspective, the present study established as the core goal to the analysis of the vision of the accompanying persons in relation to promoting playing activities in the space where the children are hospitalised.

\section{METHODS}

A qualitative study of exploratory and descriptive character inserted in the field of Social Research was conducted since "it is historically charged and so as the social theories, it reflects positions towards reality, moments of development and social dynamics, concerns and interests of certain classes and groups" (p. 23) ${ }^{15}$. The research was conducted within the standards of the Declaration of Helsinki and approved by the Ethics Committee of the Universidade do Sagrado Coração under the protocol number 102/08.

The subjects or this survey were the accompanying persons of hospitalised children who attended the playroom in a private hospital located in a medium-sized city (350,000 inhabitants) in the centre-west of the state of São Paulo.

The object in the procedure used was the meaning assigned to the playing activity including individual communications (questionnaires) of the accompanying persons who witnessed the activities in such space involving the hospitalised children.

The questionnaire consisted of open and closed questions about aspects of the playing activities developed in the playroom with children in situations of hospitalisation and it was also built based on other investigations ${ }^{4,16,17}$.

The data obtained through the protocol of personal information and the closed questions in the questionnaire were entered into the SPSS 16.0 spreadsheet. They were tabulated and went through descriptive analyses, enabling comprehensive description of the participants in this study. Open questions were analysed using content analysis.

From the answers to the questions concerning the importance of the playing activity for children, from the positive aspects that favour and influence the development of children, Chart 1 was organised for easy viewing of the answers and formed categories. 
Chart 1 Categories formed from the answers given by the accompanying persons to the questionnaire

\section{ANSWERS}

Recovery; welfare; performance improvement; cure, improvement.

Coping; cooperation with the treatment; excitement; humour, motivation; it favours the understanding of the situation; awareness of the situation.

Decreased stress; distraction; forgetfulness; relief; soothing and calmness; relaxation; decreased tension; improvement in the mood; emotional improvement; past time; time goes quickly; joy/happiness; decreased trauma; warm treatment/comfort; decreased homesick; enhanced self-esteem; minimizes the hospitalisation effects; decreased irritation; improvement in the acceptance of the diet; sleeps better; patience; independence; stopped crying; confidence; self-help; decreased resistance; no fear; freedom; love; occupation.

Communication; exchange of experiences; interaction with other children; interaction with toys; interaction with the accompanying persons (parents), interaction with the local professional; interaction with the staff; positive image of the hospital (the environment).

Educational activities: sharing of toys; development of skills; psychological development; physical development; playing activities related to the hospital context; new interests; adequate training of professionals (Occupation Therapy) organisation of toys.

Leaves the room; experiences daily activities; toys; playing activities.

Parents' decreased tension; decreased stress; rest for the parents; decreased family's stress; warmth/comfort; interaction among the children's accompanying persons; mother is happy; security.

Important; marvelous; indispensable; it provides good moments; missing it on the weekends; the child appreciates it; cool place; a place we don't want to leave.

\section{CATEGORIES}

Positive factors/aspects related to the disease.

Child's attitude towards the situation.

Palliative measures over the situation.

Interaction.

Factors which contribute to learning.

Facts which are inherent to the child's daily life.

Positive factors/aspects related to the accompanying person.

Other.
Finally, it was performed the confrontation between the results of the empirical data (questionnaire) and the theoretical one.

\section{RESULTS}

Study participants included the accompanying persons - $100 \%$ of mothers - of 65 children who entered the hospital where the survey was conducted. The children who were accompanied were $50.8 \%$ female and $49.2 \%$ male and most of them were from 2 to 6 years of age (58.5\%). As to the reasons that led children to stay in hospital, two major groups can be defined: the clinical pathologies related to diseases that caused condition of weakness, requiring more intensive medical care (pneumonia, gastrointestinal viruses, 
among others) and those admitted for surgical procedures, such as removal of adenoids, appendix, etc. There could be reported that the hospitalisation time of the children showed variation and $52.3 \%$ of them stayed up to 4 days in hospital.

According to the accompanying persons, the most appreciated space for the children during hospitalisation (96.9\%) was the playroom regarded as the most suitable area since it provided new experiences for the children. Only $1.5 \%$ reported a preference in staying in the room conducting activities brought from home and the other $1.5 \%$ of the participants pointed out both answers.

Table 1 shows the distribution of the absolute and relative frequencies of the aspects provided by the playroom to the child.

Table 1: Distribution of the absolute and relative frequencies of the aspects provided by the playroom to the child

\section{Categories}

Alleviation of the suffering from illness

It provided more calmness to the child

Stress relief

Learning to the child

Interaction with other children

Communication with other children

To know the child better

The child became more agitated

It did not favour any learning

Other

$\begin{array}{cc}\begin{array}{c}\text { Absolute } \\ \text { frequency }\end{array} & \begin{array}{c}\text { Relative } \\ \text { frequency (\%) }\end{array} \\ 59 & 90,8 \\ 55 & 84,6 \\ 53 & 81,5 \\ 38 & 58,5 \\ 38 & 58,5 \\ 27 & 41,5 \\ 18 & 27,7 \\ 1 & 1,5 \\ 0 & 0 \\ 8 & 12,3\end{array}$

Table 2 shows the distribution of the absolute and relative frequencies of answers according to the categories related to the meaning of playing for the accompanying persons of the hospitalised children. It is important to point out that this table, as well as the next ones (up to the 4th) refer to the number of positive answers for that category and not the number of the children. Each participant could indicate more than one answer. Thus, the relative frequency was assigned from the number of people who indicated that category as an answer which could allow its importance in the visualization.

Table 2: Distribution of the absolute and relative frequencies of the meaning given to the playing activity

\section{Categories}

Palliative measures over the situation

Positive factors/aspects related to the disease

Interaction

Factors which are inherent to the child's daily life

The child's attitude over the situation

Factors that contribute to the learning

Positive factors/aspects related to the accompanying person

$\begin{array}{cc}\begin{array}{c}\text { Answers } \\ \text { Absolute } \\ \text { frequency (\%) }\end{array} & \begin{array}{c}\text { Relative } \\ \text { frequency (\%) }\end{array} \\ 44 & 67,7 \\ 25 & 38,5 \\ 14 & 21,5 \\ 12 & 18,5 \\ 11 & 16,9 \\ 5 & 7,7 \\ 3 & 4,6\end{array}$

Tables 2, 3 and 4 are shown by the categorisation described in Table 1 . In relation to the meaning given to the playing activity during the hospitalisation of the child, the majority (67.7\%) of the accompanying persons believe that it stands out as a palliative factor to the situation. The second most marked answers (38.5\%) formed the category factors/positive aspects related to the disease and then followed by interaction (21.5\%).

Table 3 shows the distribution of the absolute and relative frequencies according to the most important aspects relating the activities. 
Table 3: Distribution of the absolute and relative frequencies of positive answers according to the most important aspects related to the activities

\section{Categories}

Palliative measures over the situation Positive factors/aspects related to the disease Factors that are inherent to the child's daily life Interaction

The child's attitude over the situation

Factors that contribute to learning

Positive factors/aspects related to the accompanying person Other

$\begin{array}{cc}\begin{array}{c}\text { Answers } \\ \text { Absolute } \\ \text { frequency (\%) }\end{array} & \begin{array}{c}\text { Relative } \\ \text { frequency (\%) }\end{array} \\ 37 & 56,9 \\ 12 & 18,5 \\ 10 & 15,4 \\ 7 & 10,8 \\ 6 & 9,2 \\ 5 & 7,7 \\ 5 & 7,7 \\ 0 & 0\end{array}$

According to the accompanying persons of the hospitalised children, activities are important due to the following factors: palliative measure in that situation (56.9\%), they provide positive factors in relation to the disease $(18.5 \%)$ and they allow the children to experience situations inherent to their ordinary daily life (15.4\%).

When the participants were asked if the activities contributed positively to the adverse effects of hospitalisation, $96.9 \%$ answered yes and only $3.1 \%$ did not believe that.
The accompanying persons were asked whether the child's playing activity somehow contributes to his development, while $95.3 \%$ responded positively and $4.7 \%$ could not answer this question.

Table 4 shows the distribution of the absolute and relative frequencies of the aspects that are favoured by the activity that interfere in the development of the children in the opinion of the accompanying persons.

Table 4: Distribution of the absolute and relative frequencies of the aspects favoured by the activity which interfere in the child's development

\section{Categories}

Factors that contribute to learning

Interaction

Palliative measures over the situation

The child's attitude over the situation

Positive factors/aspects related to the disease

Factors which are inherent to the child's daily life Other

$\begin{array}{cc}\begin{array}{c}\text { Absolute } \\ \text { frequency (\%) }\end{array} & \begin{array}{c}\text { Relative } \\ \text { frequency (\%) }\end{array} \\ 26 & 40,0 \\ 16 & 24,6 \\ 14 & 21,6 \\ 8 & 12,3 \\ 6 & 9,2 \\ 4 & 6,2 \\ 1 & 1,5\end{array}$

Most accompanying persons (40\%) believe that the activities of playing contribute to the child's development by encouraging learning (factors that contribute to learning) through the offering of educational activities, development of psychological and physical abilities and also by awakening new interests in the child. They also favour the interaction (24.6\%), and again they stand as a palliative measure to the situation (21.6\%).

Regarding the participation of the accompanying persons, $63.1 \%$ reported they preferred to participate with the child in the playing activities, $21.5 \%$ preferred to stay just watching over the child, $10.8 \%$ indicated that their participation did not make any remarkable difference. The remainder $(4.6 \%)$ marked the first two answers.
The accompanying persons reported that the recreational activities in the hospital allowed the children to meet and play with others (86.2\%) and meet other children, but playing alone (13.8\%).

\section{DISCUSSION}

This study was conducted with the accompanying persons of hospitalised children and the results that corresponded to mothers in $100 \%$ of cases. This is according to the research of Ribeiro and Angelo ${ }^{18}$ who studied the meaning of hospitalisation to pre-schooler children, described the importance of the presence of the mother at that moment, as well as the support she represents in dealing with the routine procedures experienced 
by the children who express their vulnerability, but also the support provided by the mother at that time. The mother's presence permeates all other established interactions. Through the interaction of the child with his mother, both of them become a single patient, even much stronger, overcoming the traumatic moments, gaining new experiences and coping positively with the hospital environment.

Authors ${ }^{19}$ suggest the importance of considering the Article 12 of the Statute of Children and Adolescents, which calls for monitoring of the hospitalised children by a family member who must be in good health conditions to remain in the place. In this regard, it should be noted that along with this measure, the determinations consist in a therapeutic action since it is through this particular accompanying person that the bond is established between the two systems, the child (represented by the family) and the health institution (unit/ paediatric team). They also emphasize that the accompanying persons function as mediators of the established relations, leading the child to feel more protected, consequently reducing the fear of coping with unknown situations.

According to the data listed in Table 2, the accompanying persons recorded in $67.7 \%$ that the playing activities are a palliative measure to the situation since they favour the reduction of stress, distraction, forgetfulness. They bring relief thus they sooth the child providing the relaxation, reduced stress and consequently the improvement in the mood state and emotional aspects. The activities were also described as pastime, providing moments of joy and happiness to the child making the trauma hospital milder.

The playing activity, besides being a form of expression, may be a structuring axis in producing models of assistance to the health of the child ${ }^{10}$.

Studies related to the topic report that the playing activities show interference in the health recovery and they reinforce that they provide the expression under a symbolic form of suffering while they are capable of giving emphasis on what has been healthier which is represented through the joy of playing, drawing and any kind of production in spontaneous and pleasant ways ${ }^{20}$.

In studies related to drawings within the hospital context, such instrument is described as a means of understanding of the emotional aspects of hospitalised children because even restricted by the disease, they need activities that promote movement, fun, excitement, therefore favouring the adaptation, preparation of requirements and restrictions imposed by the real situation ${ }^{6}$.

Cunha $^{3}$, when referring to experiences and development of the skills that the playing activity provides, states that blocking, stacking, building and assembling are activities that are effectively playful when they are performed with pleasure and those types of entertaining provide exercises and learning, so that they favour the planning of their actions.

During the sessions of the use of therapeutic toys, the playing activity also favours the symbolic game since it allows the children to act out their physical examinations, replicating the procedures by which they are submitted with dolls, parents and members of the staff in an attempt to understand their own body ${ }^{18}$.

Through those measures and the presence of the mother, the child becomes more secure, more mature, reacting positively when facing and understanding the procedures as well as the situation.

The condition of facing the situation was pointed at different times of the data collection with the accompanying persons. One of the most mentioned aspects (Table 3 ) is concerning to the playing activities as a palliative measure in the hospitalisation context, that is, it promotes the reduction of stress, providing relief and decreased trauma, so minimizing the effects of the hospitalisation. Through the therapeutic toys, the children who go through the hospitalisation make use of them to express their feelings that are derived from experiences, easing the trauma and, in a certain way, fulfilling all the needs of growing up when they go through that period ${ }^{18}$.

Also, when the children are provided with activities and spaces to play they can have a view of the hospital in another dimension which is replaced by memories and relate it to positive aspects where they can also play. The hospital is well understood as a space that generates suffering, fears and anxieties, but also provides improvement towards cure and a place to play ${ }^{19}$.

According to the participants of this research, as it can be seen in Table 4, the playing activity within the hospital context allows the child to learn new skills and awaken new interests, facilitating the interaction of the child with other children, other accompanying persons and with the hospital environment. In this context, the space that is structured to the playing activities, namely an interaction space between children and the accompanying persons, promotes an open interaction strengthening the bond between parents and children. Parents in the hospital playing context are able to establish a relationship with their children without focusing only on the perspective of the disease. Within such space, the children create, invent, transform, build and express their inner reality. That environment has the potential to offer opportunities to the children as to the choice, providing not only independence but also personal growth and towards habits of responsibility and maturing ${ }^{21}$.

The children shall have a proper and adequate environment where they can still be a child so that they can enjoy activities that are essential to their development. The space, when organised and used appropriately by a professional team, is able to provide freedom of choice, exploration, expression of feelings and discoveries. It also favours interaction with the staff, other children, enabling the exchange of experiences and new learning. The children have the chance to organise themselves, achieving more confidence and the ability to understand the routine more gently, dealing with hospitalisation and all proceedings that may appear without having their mental health affected abruptly.

It could be noticed that the accompanying persons are positively affected when they realize the capacities of the children are kept as they 
become familiar with the playful universe again so that they remain active, spontaneous, in charge of the situation, leaving behind the passivity generated by the disease. This environment provides moments of interaction among the accompanying persons who exchange their experiences, talk about their fears and challenges. It is also possible to know and learn about the playing activities, using them as a favourable resource for recovery, development and coping with the current reality by the child.

In a project which was named "Waiting Room", it was noted that the accompanying persons eventually started to learn about the potential of the toys in the hospitalisation and appreciate this after being encouraged and guided by the professionals involved in project ${ }^{21}$.

Other benefits that come from the playing activities within a structured environment is the humanisation of the health services. When it is aggregated and incorporated to the proposal, it makes the routine milder and thus less aggressive. Eventually the nurses and the health team in general start to consider the playing activities as routine. The child usually cooperates, strives to meet the "terrifying" mandatory procedures (medication, examinations, etc.), showing anxiety to return to the playing activities.

In the study about the use of toys in the hospital context in in the view of the Brazilian nurses, the authors point out that such resource not only helps the child in expressing feelings and releasing fears, stress and anxiety, but it also assists the nurse and the hospital care in aspects such as communication, performing procedures and humanising the environment ${ }^{22}$.

The hospital drama involves many aspects and characters, especially when it refers to infant hospitalisation. In this context there may be involvement of the physical, emotional and intellectual development of the children. To break their routine and the process of adaptation to the new reality, the children leave common things behind, still fundamental aspects of their development: parents, home, siblings, school, friends, pets, toys. Some authors have investigated the resources that can support the improvement of

\section{REFERENCES}

1. Angeli AAC, Luvizaro NA, Galheigo SM. O cotidiano, o lúdico e as redes relacionais: a artesania do cuidar em terapia ocupacional no hospital. Interface (Botucatu). 2012; 16(40): 261-272. Doi: http://dx.doi.org/10.1590/ S1414-32832012005000016.

2. Moreira MCN, Macedo AD. O protagonismo da criança no cenário hospitalar: um ensaio sobre estratégias de sociabilidade. Ciênc Saúde Coletiva. 2009; 14(2): 645-652. Doi: http:// dx.doi.org/10.1590/S1413-81232009 000200033.

3. Cunha NHS. Brinquedoteca: um mergulho no brincar. 4.ed. São Paulo: Aquariana, 2007.

4. Vieira T, Carneiro MS. O brincar na sala de espera de um ambulatório pediátrico: possíveis the health care to the child considering public policies and other issues such as the structuring of appropriate environments for children, the presence of accompanying persons, trained health staff and respect to the Rights of Children and Adolescents $2,23,24,25$.

\section{FINAL CONSIDERATIONS}

This survey found that the organisation of areas to play within the hospital environment where it could be offered activities under the supervision of a trained professional provides a special service in the scenario of the infant hospitalisation which helps in coping with adverse situations, thus facilitating the recovery process.

The condition of performing playing activities should not be eliminated when children become ill or are hospitalised since such activity has the potential to develop important aspects such as the ability to feel safe in environments with unknown people. When providing conditions and contact to the children in the playing activities, they undergo a process of organisation of the reality and its creation.

This approach favours a better adaptation of the entire family during hospitalisation and a less troubled relationship with the child. Parents feel comfortable in learning that their child is able to carry out the activities on his daily activities. Frequently such playroom provides the accompanying persons moments of rest and some time left for unresolved personal problems. Offering the activities in a unique space provides the children and their accompanying person a warm and secure environment, which is very close to the daily situations.

There can never be enough discussion of this subject, but this study presents a contribution to the knowledge related to the area and it can be deepened through investigation exploring the views of the children themselves, the professionals involved in the treatment and also a more systematic observation of the environment and the system of the relations that are established in it.

significados. In: Bomtempo E, Antunha EG, Oliveira VB. (orgs.) Brincando na escola, no hospital, na rua... Rio de Janeiro: Wak, 2006. p. 75-110.

5. Pérez-Ramos $A M Q$. O ambiente na vida da criança hospitalizada. In: Bomtempo E, Antunha EG, Oliveira VB. (orgs.) Brincando na escola, no hospital, na rua.... Rio de Janeiro: Wak, 2006. p. 111-125.

6. Motta AB, Enumo SRF. Brincar no hospital: estratégia de enfrentamento da hospitalização infantil. Psicol Estud. 2004; 9(1): 19-28. Doi: http://dx.doi.org/10.1590/S1413-73722 004000100004.

7. Pedrosa AM, Monteiro H, Lins K, Pedrosa F, Melo C. Diversão em movimento: um projeto lúdico para crianças hospitalizadas no Serviço de Oncologia Pediátrica do Instituto Materno In- 
fantil Prof. Fernando Figueira, IMIP. Rev Bras Saude Mater Infant. 2007; 7(1): 99-106. Doi: http://dx.doi.org/10.1590/S151938292007000100012.

8. Carvalho AM, Begnis JG. Brincar em unidades de atendimento pediátrico: aplicações e perspectivas. Psicol Estud. 2006; 11(1): 109-117.

9. Oliveira SSG, Dias MGBB, Roazzi A. O lúdico e suas implicações nas estratégias de regulação das emoções em crianças hospitalizadas. Psicol Reflex Crit. 2003; 16(1): 1-13. Doi: http:// dx.doi.org/10.1590/S0102-79722003 000100003.

10. Mitre RMA, Gomes R. A promoção do brincar no contexto da hospitalização infantil como ação de saúde. Ciênc Saúde Coletiva. 2004; 9(1): 147-154. Doi: http://dx.doi.org/10.1590/ S1413-81232004000100015.

11. Ministério da Saúde (BR). Secretaria de Assistência à Saúde. Programa Nacional de Humanização da Assistência Hospitalar. Brasília: Ministério da Saúde, 2001.

12. Carvalho A, Vieira T. Laboratório do brincar: curso, per-curso, ações e reflexões sobre o brincar. In: Carvalho, A. et al. (orgs.) Brincar(es). Belo Horizonte: editora UFMG; Pró-Reitoria de extensão/UFMG, 2005. p. 153-166.

13. Kishimoto TM. Diferentes tipos de brinquedotecas. In Friedmann, A. O direito de Brincar: a brinquedoteca. 4 ed. São Paulo: Abrinq, 1998. p. 53-63.

14. Ferland F. O modelo lúdico: o brincar, a criança com deficiência física e a terapia ocupacional. 3 ed. São Paulo, Roca, 2006.

15. Minayo MCS. O desafio do conhecimento: pesquisa qualitativa em saúde. 7. ed. São Paulo: Hucitec; Rio de Janeiro: Abrasco, 2000.

16. Mitre RMA. A experiência da promoção do brincar em hospitias. Tese (Doutorado) - Instituto Fernandes Figueira, Fundação Oswaldo Cruz. Rio de Janeiro: 2004.

17. Moraes MCAF. A influência das atividades expressivas e recreativas em crianças hospitali- zadas com fissura labiopalatina: a visão dos familiares. Dissertação (Mestrado) - Universidade de São Paulo. Bauru: 2007.

18. Ribeiro CA, Angelo M. O significado da hospitalização para a criança pré-escolar: um modelo teórico. Rev Esc Enferm USP. 2005; 39(4): 391-400. Doi: http://dx.doi.org/10.1590/ S0080-62342005000400004.

19. Quintana A, Arpini D, Pereira C, Santos M. A vivência hospitalar no olhar da criança internada. Ciênc Cuid Saúde. 2007; 6(4): 414-423. Doi: http://dx.doi.org/10.4025/ cienccuidsaude.v6i4.3679.

20. Dietz KG, Oliveira VB. Brinquedotecas hospitalares, sua análise em função de critérios de qualidade. Bol Acad Paul Psicol. 2008; 28(1): 100-110.

21. Ferreira $A L$, Pinto ADV, Parreira FV, Gonçalves GB, Coelho ZAC. O brincar como mediador da relação pais e filhos no contexto ambulatorial e hospitalar: relato de uma experiência. Encontro de Extensão da UFMG. Belo Horizonte: 2005.

22. Leite TMC, Shimo AKK. Uso do brinquedo no hospital: o que os enfermeiros brasileiros estão estudando? Rev Esc Enferm USP. 2008; 42(2): 389-95 http://dx.doi.org/10.1590/ S0080-62342008000200025.

23. Azevedo DM, Santos JJS, Justino MAR, Miranda FAN, Simpson CA. O brincar enquanto instrumento terapêutico: opinião dos acompanhantes. Rev Eletr Enf. 2008; 10(1): 137-144.

24. Bortolote GS, Brêtas JRS. O ambiente estimulador ao desenvolvimento da criança hospitalizada. Rev Esc Enferm USP. 2008; 42(3): 422-429. Doi: http://dx.doi.org/ 10.1590/S0080-62342008000300002.

25. Mitre RMA, Gomes R. A perspectiva dos profissionais de saúde sobre a promoção do brincar em hospitais. Ciênc Saúde Coletiva. 2007; 12(5): 1277-84. Doi: http://dx.doi.org/ 10.1590/S1413-81232007000500025. 


\section{RESUMO:}

Introdução: a hospitalização infantil pode comprometer o desenvolvimento normal da criança, em decorrência da quebra de sua rotina e do processo de adaptação à nova realidade. São várias as iniciativas no sentido de promover espaços em hospitais que possibilitem à criança contato com atividades lúdicas. Muitas são as variáveis que influenciam a atitude da criança perante a possibilidade de realização de atividades lúdicas, dentre elas, a participação dos acompanhantes. Saber qual a interpretação dos mesmos sobre o brincar no contexto hospitalar e quais as características que associam a essa atividade é essencial para melhor planejamento das ações de atendimento. Objetivo: esta pesquisa teve por objetivo analisar a opinião dos acompanhantes sobre a promoção do brincar no espaço de hospitalização da criança. Método: para tanto, os acompanhantes responderam a questionários durante o período de internação. Os dados foram analisados através de estatística descritiva e análise de conteúdo. Participaram do estudo 65 mães de crianças internadas, sendo que a maioria acompanhava pacientes na faixa etária entre 2 a 6 anos. Resultados: todas avaliaram que a criança deve participar da brinquedoteca, pois auxilia na recuperação, propiciando alívio do sofrimento, acalmando a criança e aliviando as tensões. Conclusão: conclui-se os acompanhantes consideram importante a brinquedoteca no contexto de hospitalização das crianças para amenizar efeitos da internação e auxiliar no desenvolvimento infantil.

Palavras-chave: brincar, hospital, acompanhantes. 